\title{
Bio-processing of macroalgae Palmaria palmata: metabolite fractionation from pressed fresh material and ensiling considerations for long-term storage
}

\author{
J. A. Gallagher ${ }^{1}$ - J. M. M. Adams ${ }^{1}$ (D) - L. B. Turner ${ }^{1}$ - M. E. Kirby ${ }^{2}$ - T. A. Toop ${ }^{2}$ - M. W. Mirza ${ }^{2} \cdot$ M. K. Theodorou $^{2}$
}

Received: 23 June 2020 / Revised and accepted: 30 September 2020 / Published online: 19 October 2020

(C) The Author(s) 2020

\begin{abstract}
Red algae, belonging to the phylum Rhodophyta, contain an abundance of useful chemicals including bioactive molecules and present opportunities for the production of different products through biorefinery cascades. The rhodophyte Palmaria palmata, commonly termed dulse or dillisk, grows predominantly on the northern coasts of the Atlantic and Pacific Oceans and is a well-known snack food. Due to its abundance, availability and cultivation capacity, P. palmata was selected for study as a potential candidate for a biorefinery process. In addition to studying juice and solid fractions of freshly harvested $P$. palmata, we have investigated the novel possibility of preserving algal biomass by ensilaging protocols similar to those employed for terrestrial forage crops. In the metabolite partitioning within the solid and liquid fractions following screw-pressing, the majority of the metabolites screened for-water soluble carbohydrates, proteins and amino acids, lipids, pigments, phenolics and antioxidant activity-remained in the solid fraction, though at differing proportions depending on the metabolite, from $70.8 \%$ soluble amino acids to $98.2 \%$ chlorophyll $a$ and $98.1 \%$ total carotenoids. For the ensiling study, screw-pressed P. palmata, with comparative wilted and chopped, and chopped only samples, were ensiled at scale with and without Safesil silage additive. All samples were successfully ensiled after 90 days, with screw-pressing giving lower or equal $\mathrm{pH}$ before and after ensiling compared with the other preparations. Of particular note was the effluent volumes generated during ensiling: 26$49 \%$ of the fresh weight, containing $16-34 \%$ of the silage dry matter. This may be of advantage depending on the final use of the biomass.
\end{abstract}

Keywords Biorefining $\cdot$ Dulse $\cdot$ Effluent $\cdot$ Rhodophyta $\cdot$ Screw-pressing $\cdot$ Seaweed $\cdot$ Silage

\section{Introduction}

Green biorefining aims to optimize the use of biomass to ensure that resources are fully exploited through the production of various marketable products in coordinated process streams (Yuan and Macquarrie 2015). The development of new fractionation processes in green biorefineries to produce, for example, proteins, bio-based platform chemicals (building

J. M. M. Adams

jaa@aber.ac.uk

1 Institute of Biological, Environmental and Rural Sciences, Aberystwyth University, Gogerddan, Aberystwyth, Ceredigion SY23 3EE, UK

2 Agricultural Centre for Sustainable Energy Systems, Department of Agriculture and the Environment, Harper Adams University, Newport, Shropshire TF10 8NB, UK blocks made from renewable materials which can be converted to a wide range of chemicals or materials), food additives, therapeutics, fermentation media, animal feed and biofuels from various biomass sources is of increasing importance in the light of concerns over global climate change as the supply of fossil raw materials decreases (Martel et al. 2011; Kamm et al. 2016). Interest is growing in the use of marine algae as feedstocks, as they have high productivity and do not compete with food production for land use and fresh water (Loureiro et al. 2015; Suutari et al. 2015) or require fertilizers (Adams et al. 2017). However, their high water content has energy cost implications that may be inhibitory during biomass preparation processes when working at scale (Suutari et al. 2015; Soomro et al. 2016), as does macroalgae's rapid decomposition once harvested with ensiling one route to longer-term preservation (Gallagher et al. 2018). Therefore, it is appropriate to investigate both rapid processing and longer-term products from preserved macroalgae. In this study both by ensiling 
and applying a cost-efficient technique for dewatering used on many land crops, screw-pressing (Takara and Khanal 2011; Kamm et al. 2016).

Large brown macroalgae, especially kelps, are high biomass producing macroalgae commonly considered for biofuel and biorefinery applications. However, these species cannot be significantly dewatered by screw-pressing when fresh (Adams et al. 2017; Gallagher et al. 2017) due to the alginate proportion present. In contrast, Palmaria palmata (L.) Weber and Mohr will press successfully upon harvesting to produce a deep red juice (Gallagher et al. 2018). Palmaria palmata is a red alga (Rhodophyta) which grows on the northern coasts of the Atlantic and Pacific Oceans and is one of the more popular seaweeds for human consumption. This particularly occurs in the west along the north Atlantic shores of Europe and America (Mouritsen et al. 2013) where it has common names including dulse or dillisk. It has been widely studied over the last 100 years or so (Morgan et al. 1980) and has been shown to contain numerous metabolites of commercial value. It has also been nutritionally considered to be one of the best algal alternatives to cereals in food and feed (Maehre et al. 2014). Techniques for the commercial cultivation of this species have been demonstrated and include growth on longlines (Harnedy et al. 2014) and in land-based tanks, producing relatively uniform algal biomass in a controlled and sustainable manner (Banskota et al. 2014). Although it is less economically viable than kelp species to farm, the $P$. palmata yield reported by Werner and Dring (2011) was $750 \mathrm{~g}$ per linear metre of culture string after about 5 months.

Palmaria palmata contains a number of carbohydrates identified as having therapeutic qualities, e.g. anti-tumour, anti-viral and anti-coagulant properties (Courtois et al. 2008; Shi et al. 2017), and/or with a commercial value in food processing and industry such as stabilizers, thickeners, emulsifiers and gelling agents (Holdt and Kraan 2011; Mutripah et al. 2014). The algae has a relatively high content of quality protein $(21.9 \% \pm 3.5 \%)$ in the winter-spring (Galland-Irmouli et al. 1999; Misurcova et al. 2014) and essential amino acids

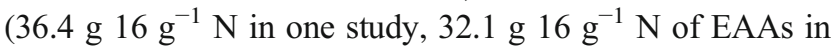
another); (Galland-Irmouli et al. 1999; Misurcova et al. 2014) and the peptides produced by hydrolysis of water- and alkalisoluble protein extracts have also been shown to have therapeutic values (Harnedy and FitzGerald 2013; Harnedy et al. 2014). This species is also noted for its high lipid content with high polyunsaturated fatty acids (49.8\% FAME content) and high $\omega-3$ eicosapentaenoic acid content $(0.44-0.58 \%$ dry weight) in comparison with other macroalgae (van Ginneken et al. 2011; Schmid et al. 2014). The phenolic content of red algae is generally low ( $<0.4 \%$ dry weight) (Holdt and Kraan 2011), but $P$. palmata has been shown to contain several hydrophilic antioxidant metabolites with potential uses as food additives to improve shelf life (Wang et al. 2010; Farvin and Jacobsen 2013). Palmaria palmata also contains photosynthetic pigments which are in increasing demand as natural colourants. Additionally, phycoerythrin, a major red pigment in $P$. palmata, is also reported to have anti-tumour, anti-oxidant, anti-diabetic, immunosuppressive and antihypertensive activities (Sekar and Chandramohan 2008; Holdt and Kraan 2011; Dumay et al. 2013). Low-cost screw-pressing, unlike many other methods commonly employed in the laboratory for the extraction of metabolites, can easily be scaled up to industrial level processing (Dumay et al. 2013; Harnedy and FitzGerald 2013). The juice derived from screw-pressing is therefore a possible source of a range of interesting compounds, though the partitioning of metabolites between the press residue and juice will be critical. The other advantage of screw-pressing is that it produces a residue with increased dry matter (DM) content indicating a potential for improved ensiling (Gallagher et al. 2018).

Ensiling provides a longer-term method of preserving the algae biomass and can provide material suitable for biofuel production, such as fermentation to ethanol or anaerobic digestion to methane. Ensiling also causes dewatering through effluent leaching (Johnson et al. 2005) which can remove more water from the biomass prior to processing. Water can also be lost through wilting, and ensiling can be improved through the inclusion of additives.

The study presented here reflects two scenarios, conducted on the same collection of biomass, showing alternative routes for the processing and storage of P. palmata. Palmaria palmata was screw-pressed when fresh, with the work described here focussing on the partitioning of valuable metabolites and compounds of interest between the liquid and solid fractions generated following screw-pressing. The second explores alternative pre-treatment processing; ensiling additive effects on the silage quality and its dewatering; and the organic acid production of ensiled $P$. palmata. These are important as ensiling does provide longer-term stability of the macroalgae and the dewatering of the biomass may be of an advantage depending on which final use the biomass is planned for. Both scenarios are novel and will contribute to a greater understanding of processing both $P$. palmata and other macroalgae in the future. This in turn will be necessary for planning and establishing biorefining protocols in future using this valuable resource.

\section{Materials and methods}

Macroalgal material Palmaria palmata was concurrently harvested at low tide from wild stock at Langland Bay, Gower, Swansea, Wales, SA3 4SQ (ordnance survey reference SS 606872), and Bracelet Bay, Gower, Swansea, Wales, SA3 4JT (ordnance survey reference SS 626868), around noon on 16 June 2015 . Approximately $16 \mathrm{~kg}$ was collected from each bay in a sustainable manner and the $32 \mathrm{~kg}$ processed 
within $2 \mathrm{~h}$ of collection. Nine $\mathrm{kg}$ was put to wilt (partial drying in air) on a plastic sheet in a ventilated shed. The remaining $23 \mathrm{~kg}$ was covered in seawater and stored in a cold room at $4{ }^{\circ} \mathrm{C}$ overnight before screw-pressing or chopping on 17 June 2015.

Screw-pressing Sixteen kilogrammes of non-wilted biomass was passed through a CP-4 screw-press (Vincent Corporation, Tampa, FL, USA) producing just under a 10-kg solid residue and a liquid termed 'juice' which contained small particulates. The juice was sieved to remove large particulates to give a final volume of 3.5 L. This liquid was frozen and stored at $20{ }^{\circ} \mathrm{C}$ prior to analysis. Samples of the solid residue were freeze-dried and stored in a desiccator until metabolite analyses were undertaken.

Screw-pressed metabolite analyses Before analyses, the freeze-dried solid residue was milled with an A11 Basic IKA mill (IKA, Germany) to pass through a $1.18-\mathrm{mm}$ sieve. Juice was thawed and centrifuged at $2400 \times g$, room temperature for $10 \mathrm{~min}$ to remove residual solid fibres. These fibres produced pellets which were combined, washed twice with water and freeze-dried; they are subsequently referred to as 'juice-pellet'. Mean metabolite concentrations were determined from triplicate extractions. Concentrations for the milled residue were given on a fresh weight (FW) basis using its mean $\% \mathrm{DM}$ as this gives a more direct comparison with concentrations in the juice.

Carbohydrates Water-soluble carbohydrates (WSC) were extracted from the solid residue and the juice-pellet with deionized cold water at room temperature and (separately) with deionized hot water in a boiling water bath for $5 \mathrm{~min}$. The juice was analysed directly. The WSC were quantified using the anthrone colorimetric assay (Yemm and Willis 1954) at a titre-plate scale (Farrar et al. 2012) against galactose rather than fructose standards.

Proteins and free amino acids Proteins were extracted from the solid residue and the juice-pellet with deionized water, $0.1 \mathrm{M}$ sodium hydroxide or $1 \%$ sodium dodecyl sulphate (SDS) in a shaking incubator at $25{ }^{\circ} \mathrm{C}$ for $3 \mathrm{~h}$ and then quantified against bovine serum albumin standards through the Lowry method (Lowry et al. 1951) at a titre-plate scale. The juice was analysed directly. Free amino acids were extracted from the solid residue (average $15.8 \mathrm{mg}: 1 \mathrm{~mL}$ ) and the juice-pellet (average $7.4 \mathrm{mg}: 1 \mathrm{~mL}$ ) by steeping in $100 \%$ methanol overnight at $4{ }^{\circ} \mathrm{C}$ in the dark. The juice was also diluted (1 mL: $3.5 \mathrm{~mL})$ with $100 \%$ methanol and stored overnight at $4{ }^{\circ} \mathrm{C}$ in the dark. Total free amino acids were measured using the ninhydrin assay (Yemm and Cocking 1955) as modified by Ferguson and Sims (1974), but also replacing 2-methoxyethanol with ethanol. Glutamate and leucine were used as standards and produced equal reactions; a mean standard curve was calculated for quantification.

Lipids Lipid analysis was by gravimetric means and was based on the general method of Folch et al. (1957) for total lipid extraction, though modified to minimize the co-extraction of chlorophyll (Zhao et al. 2018). The solid residue was extracted twice with acidified 2:1 dichloromethane:methanol (sulphuric acid was added to the solvent to a final concentration of $0.1 \mathrm{M}$ $\mathrm{H}_{2} \mathrm{SO}_{4}$ ). Solid material was removed by centrifugation and the supernatant phase-separated with $0.9 \%$ sodium chloride. The upper aqueous phase was discarded and the interface was washed three times with $1 \mathrm{~mL} \mathrm{1:1} \mathrm{methanol:water.} \mathrm{The} \mathrm{lower}$ phase was transferred to a glass evaporating dish and dried. The juice was acidified to a final concentration of $0.1 \mathrm{M}$ sulphuric acid and then mixed with methanol and dichloromethane in the ratio of 3:12:5 to give a homogeneous solution. This was phase-separated by the addition of dichloromethane (5 parts) and deionized water ( 5 parts) and then processed as above, except that any coagulated material on the interface was carefully removed before washing the interface with methanol:deionized water. The dried lipid samples were further extracted into two 5-mL washes of hexane, which were transferred to pre-weighed glass dishes and dried to constant weight. The final lipid samples had a negligible observable green colour.

Pigments Pigments were analysed in the solid residue and the juice-pellet by steeping overnight at $4{ }^{\circ} \mathrm{C}$ in the dark with the extraction mediums (detailed below). The juice was also diluted with the extraction mediums and left overnight at $4{ }^{\circ} \mathrm{C}$ in the dark.

Phycoerythrin was extracted in 0.1-M potassium phosphate buffer, $\mathrm{pH}$ 6.5. Spectra between 350 and $750 \mathrm{~nm}$ and absorbance at 564, 618 and $730 \mathrm{~nm}$ were recorded with a UV/Vis spectrometer UV4 (UNICAM, now Thermo Fisher Scientific, USA) running VisionPro software, which was used to also calculate derivatives of the spectral curves to confirm phycoerythrin presence before quantifying using the equation within Sampath-Wiley and Neefus (2007).

Chlorophylls and carotenoids were extracted in $100 \%$ methanol and absorbance recorded at $470 \mathrm{~nm}, 653 \mathrm{~nm}$ and $666 \mathrm{~nm}$. Quantification was produced from these absorbances using published equations (Lichtenthaler and Wellburn 1983).

Phenolics and antioxidants The solid residue and the juicepellet were extracted in duplicate biological replicates by steeping in deionized water overnight at room temperature in the dark. The extracts were combined and stored at $-20{ }^{\circ} \mathrm{C}$. The juice was diluted as necessary and analysed directly. Phenolic acids were quantified by the Folin-Ciocalteu reaction against a gallic acid standard and expressed as mg gallic acid 
equivalents. Antioxidant activity was assessed by diphenylpicrylhydrazyl (DPPH) scavenging capacity (Farvin and Jacobsen 2013) measured at $517 \mathrm{~nm}$ on the same extracts. Sample dilution curves including minus sample controls (for zero scavenging) and paired minus reagent blanks (for background absorbance) were analysed, and scavenging capacity $(\%)$ is calculated as shown in Eq. 1:

$$
\begin{aligned}
& \operatorname{Capacity}(\%) \\
& =\left(1-\left(\frac{\text { sample } \left.A_{517}-\text { reagent blank } A_{517}\right)}{\text { sample control } A_{517}-\text { reagent blank } A_{517}}\right)\right) \\
& \quad \times 100
\end{aligned}
$$

The data are expressed as $\mathrm{EC}_{50}$ values (the sample concentration required to give $50 \% \mathrm{DPPH}$ scavenging). The $\mathrm{EC}_{50}$ for the reference compound ascorbic acid was $5.7 \mu \mathrm{g} \mathrm{mL}^{-1}$ under the same conditions.

Ensiling pre-treatments Approximately $7 \mathrm{~kg}$ of $P$. palmata stored in seawater overnight and the $9 \mathrm{~kg}$ (initial weight) of wilted $P$. palmata were chopped with a garden shredder (Viking GE-250 Stihl, UK) to discrete pieces that were approximately $3 \times 2 \mathrm{~cm}$ mimicking the particle size of screwpress residue material. These, and the solid residue minus samples from the $16 \mathrm{~kg}$ (initial weight) screw-pressed P. palmata, were then used to produce ensiled material for the storage study.

Ensiling Safesil (Kelvin Cave Ltd., Langport, UK) is a terrestrial crop silage additive manufactured to contain a mixture of the food-safe preservatives, sodium benzoate, sodium nitrate and potassium sorbate. Biomass from each pre-processing technique were labelled as SP, screw-pressed; Ch, chopped only; WCh, wilted, then chopped. Each pre-processing sample was divided into two and treated with either Safesil silage additive (A) or an equivalent amount of tap water (control, C) prior to ensiling. Therefore, the six different treatments were SPA, SP-C, Ch-A, Ch-C, WCh-A and WCh-C. Both the additive and control treatments were applied at the recommended dosage rate of $4 \mathrm{~mL} \mathrm{~kg}^{-1} \mathrm{FW}$ for the Safesil product.

To produce the silage, 3-kg batches of each pre-processing sample were spread onto plastic sheeting and sprayed uniformly with Safesil (A) or water (C) applications, shaken within the sheet for $2 \mathrm{~min}$ and resprayed with three mixing and spraying replications in total.

Immediately after the spray treatments, triplicate $500 \mathrm{~g}$ samples of each treated biomass were sealed in 160 - $\mu \mathrm{m}$-thick embossed food grade vacuum seal bags $(30 \times 50 \mathrm{~cm}$; Lava, Germany) using a vacuum packaging laboratory-scale ensilage process similar to that described by Johnson et al. (2005). A V400OP commercial vacuum packer (Lava) was used to remove air from the bags to a pressure of -0.9 bar and triple heat sealed before being stored at approximately $15{ }^{\circ} \mathrm{C}$ for 90 days. Sub-samples from each of the treatments were removed after the addition of Safesil or water but prior to ensiling, with fractions analysed immediately or stored at $-20{ }^{\circ} \mathrm{C}$ prior to subsequent analyses.

Silage analyses On day 90 of ensilage, bags were inverted to drain the large volume of effluent from the solids (Fig. 1), with the lowest corners cut and the collected effluent volumes recorded. The DM content of the solid and effluent fractions were determined by oven drying $4 \mathrm{~g}$ samples (duplicate samples per bag) to constant weight at $60^{\circ} \mathrm{C}$ using a UF260 oven (Memmert, Germany).

Ensiled solid and effluent $\mathrm{pH}$ measurements The $\mathrm{pH}$ of the ensiled solid fraction was determined for each replicate silage bag. A 10-g sample was weighed into a Stomacher bag (Seward, Worthing, UK) with $90 \mathrm{~g}$ of deionized water. The sample was pummelled for $3 \mathrm{~min}$ at $230 \mathrm{rpm}$ using a Stomacher 400 Circulator (Seward) and the $\mathrm{pH}$ measured immediately using a calibrated Jenway $3505 \mathrm{pH}$ meter with temperature probe (Cole-Palmer, UK). The previously separated silage effluent fraction was measured directly using the same $\mathrm{pH}$ and temperature probe.

Lactic acid and other volatile acids Compositional analyses of the ensiled solid fraction were determined by weighing a $20 \mathrm{~g}$ sample into a new Stomacher bag with $100 \mathrm{~g}$ of highperformance liquid chromatography grade water. The sample was pummelled as detailed above and the liquid removed for analysis. The liquid obtained from solid extracts and the liquid

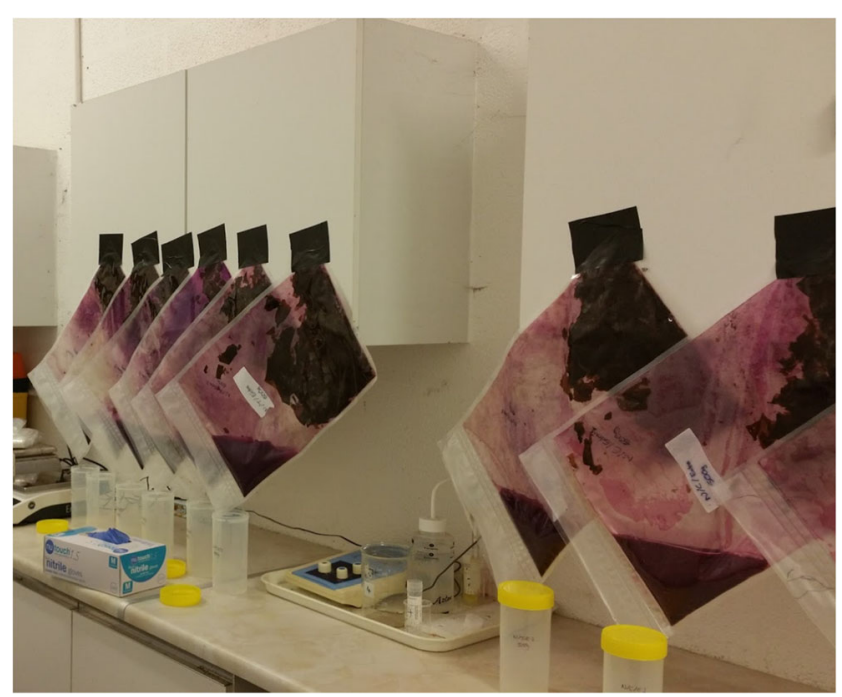

Fig. 1 Day 90 ensiled seaweed demonstrating the volume of liquid effluent produced per treatment 
effluent fraction from the ensilage bag were filtered through a 25-mm, 0.45- $\mu \mathrm{m}$ nylon syringe filter (Chromatography Direct Ltd., UK) into Low EVap Filter Vials (Thomson Instrument Company, USA) with 3-methylpentanoic acid used as an internal standard at a final concentration of $1 \mathrm{mg} \mathrm{mL}^{-1}$. The vial was capped and vortexed for $30 \mathrm{~s}$. Analysis was performed using an Agilent 1100 HPLC system (Agilent Technologies, UK) consisting of binary pump, solvent degasser, autosampler, column oven and diode array detector. Method conditions consisted of a $0.6 \mathrm{~mL} \mathrm{m^{-1 }}$ flow rate of $5 \mathrm{mM}$ sulphuric acid through an Aminex HPX-87H column (BioRad Laboratories Ltd., UK) maintained at $55^{\circ} \mathrm{C}$ with UV detection at $210 \mathrm{~nm}$. Internal standards were used to detect succinic, lactic, formic, acetic, propionic, isobutyric, butyric, isovaleric and valeric acids in liquid samples. Individual samples from solid and effluent fractions were analysed per triplicate set of bags, each analysed twice from the same HPLC vial.

Statistical analyses Data were analysed using GenStat edition 18 (VSN International, UK). Metabolite concentrations were analysed by one-way analysis of variance. Two-way analysis of variance was used to determine significances for silage composition analyses (pre-processing techniques $\times$ additive type). Differences between means were assessed with Fisher's protected least significant difference $(P \leq 0.050)$.

\section{Results}

Metabolite fractionation of $P$. palmata by screw-pressing The concentrations of the major classes of algal metabolites were measured in the solid residue, clarified juice and juice-pellet obtained from the screw-press using predominantly spectrophotometric assays (Table 1). Because the yields of the fractions differed between categories, the percentage of the total biomass content recovered in these fractions is also of interest and is therefore included in Table 1 . The ash content for each fraction was determined as $66.1 \% \pm 0.64 \mathrm{std}$. dev. dry solids with no significant differences seen between any treatment ( $n=6, P<0.001$, analysis not shown).

Most of the carbohydrate detected by the anthrone assay and measured as galactose equivalents was released from the solid residues with cold water. Using hot water to extract released a small proportion of additional WSC, increasing the measured WSC content from $15.32 \mathrm{mg} \mathrm{g}_{\mathrm{FW}}{ }^{-1}$ (cold extract) to $17.78 \mathrm{mg} \mathrm{g}_{\mathrm{FW}}{ }^{-1}$ (hot extract). In contrast, the juicepellet released no WSC in a cold extract, but did contain $5.74 \mathrm{mg} \mathrm{g}_{\mathrm{DW}}{ }^{-1}$ after a hot extraction. The juice was measured directly, and its production was most similar to the cold process, but the quantity released $\left(10.3 \mathrm{mg} \mathrm{mL}^{-1}\right)$ has been replicated in Table 1 in the hot extraction row too to allow comparisons to be made with the other fractions. The carbohydrate content of the juice was approximately two-thirds that of the solid residue, equating to a recovery of just under $20 \%$ of the total WSC.

Protein was found in all fractions (Table 1). Just over half the protein in the solid residue was water soluble; alkali and the detergent SDS were almost equally effective at releasing the remainder. The juice-pellet did not contain water-soluble protein but did contain significant amounts of non-watersoluble protein, particularly protein amenable to release with alkali. Due to the liquid nature of the juice fraction, only one direct measurement of protein concentration is possible for juice. This number has been replicated in Table 1 under the different soluble protein categories as above to allow comparisons with the other materials analysed. The juice contained $1.04 \mathrm{mg} \mathrm{mL}^{-1}$ protein, approximately one quarter of the water-soluble concentration found in the solid residue on a FW basis. This equated to recovery of $7.6 \%$ of total biomass water-soluble protein in the juice. The concentration of free amino acids was slightly, but not significantly, higher in the juice than in the solid residue on a FW basis. This resulted in a much higher fractionation, with nearly $30 \%$ partitioning into the juice (Table 1). Preliminary investigation of the amino acid complement of the juice by HPLC-MS (with identity based purely on nominal mass and ion fragmentation spectra) showed the presence of the essential amino acids lysine, histidine, phenylalanine and leucine plus also glutamate, aspartate and proline; collectively, these are presented as 'soluble amino acids' in Table 1.

Lipids were not measured in the juice-pellet as insufficient material was available for the scale of gravimetric analyses but were found in both the solid and juice fractions. The solid residue contained $0.58 \mathrm{mg} \mathrm{g}_{\mathrm{FW}}{ }^{-1}$ (Table 1). Significantly less lipid $(P=0.12)$ was present in the juice, only $0.05 \mathrm{mg} \mathrm{mL}^{-1}$ which equated to recovery of $2.9 \%$ total biomass lipid from pressing.

Compounds from three classes of pigment (phycobiliprotein, chlorophyll and carotenoid) from the light harvesting complexes found in red algae were measured. The pigment with the highest concentration in juice was the phycobiliprotein phycoerythrin (Table 1). The juice contained very little chlorophyll or carotenoid, though significant concentrations of these were present in the juice-pellet. Nevertheless, overall less than $3 \%$ of the pigments present in the biomass was released into the juice by screw-pressing.

There were highly significant $(P<0.001)$ differences between the concentrations of phenolic compounds between the three fractions (Table 1). The juice had the lowest concentration of phenolics, with just over $10 \%$ partitioned into the juice by screw-pressing. Antioxidant activity was assessed by DPPH scavenging capacity, and $\mathrm{EC}_{50}$ values are presented (Table 1). The fraction/extract concentration required for $\mathrm{EC}_{50}$ was higher for the juice than for the solid residue; there was more activity in $1 \mathrm{~g}$ residue than in $1 \mathrm{~mL}$ juice. Interestingly, no detectable decolouration was measured in 
Table 1 Metabolite content of screw-press residue, juice fractions and total yield partitioning between the fractions

\begin{tabular}{|c|c|c|c|c|c|c|c|}
\hline \multirow[t]{2}{*}{ Metabolite } & \multicolumn{4}{|l|}{ Material } & \multirow[b]{2}{*}{$P$ value } & \multicolumn{2}{|l|}{ Yield } \\
\hline & $\begin{array}{l}\text { Residue per g dry } \\
\text { weight }\end{array}$ & $\begin{array}{l}\text { Residue per } \mathrm{g} \text { fresh } \\
\text { weight }\end{array}$ & Juice per mL & $\begin{array}{l}\text { Juice-pellet per g dry } \\
\text { weight }\end{array}$ & & $\begin{array}{l}\text { Residue } \\
\text { (\% total) }\end{array}$ & $\begin{array}{l}\text { Juice }+ \text { pellet } \\
\text { (\% total) }\end{array}$ \\
\hline \multicolumn{8}{|l|}{ Carbohydrates-WSC } \\
\hline Cold water soluble (mg) & 85.91 & $15.32^{\mathrm{c}}$ & $10.30 * \mathrm{~b}$ & $0^{\mathrm{a}}$ & $<0.001$ & 80.7 & 19.3 \\
\hline Hot water soluble (mg) & 99.75 & $17.78^{\mathrm{b}}$ & $10.30 *^{\mathrm{a}}$ & $5.74^{\mathrm{a}}$ & 0.012 & 82.9 & 17.1 \\
\hline \multicolumn{8}{|l|}{ Proteins/amino acids } \\
\hline Water-soluble protein (mg) & 24.87 & $4.43^{\mathrm{b}}$ & $1.04 *^{\mathrm{a}}$ & $0^{\mathrm{a}}$ & $<0.001$ & 92.4 & 7.6 \\
\hline Alkali-soluble protein (mg) & 44.07 & $7.85^{\mathrm{a}}$ & $1.04 *^{\mathrm{a}}$ & $94.38^{\mathrm{b}}$ & $<0.001$ & 94.8 & 5.2 \\
\hline SDS-soluble protein (mg) & 41.26 & $7.34^{\mathrm{a}}$ & $1.04 *^{\mathrm{a}}$ & $16.24^{\mathrm{b}}$ & 0.018 & 95.1 & 4.9 \\
\hline Soluble amino acids ( $\mu \mathrm{mol})$ & 44.73 & $7.96^{\mathrm{a}}$ & $9.24^{\mathrm{b}}$ & $20.26^{\mathrm{c}}$ & $<.001$ & 70.8 & 29.2 \\
\hline \multicolumn{8}{|l|}{ Lipids } \\
\hline Total (mg) & 3.28 & 0.58 & 0.05 & n.d. & 0.012 & 97.1 & 2.9 \\
\hline \multicolumn{8}{|l|}{ Pigments } \\
\hline Phycoerythrin (mg) & 6.078 & $1.082^{\mathrm{b}}$ & $0.071^{\mathrm{a}}$ & $0.110^{\mathrm{a}}$ & $<0.001$ & 97.7 & 2.3 \\
\hline Chlorophyll $a$ (mg) & 1.502 & $0.267^{\mathrm{b}}$ & $0.010^{\mathrm{a}}$ & $1.801^{\mathrm{c}}$ & $<0.001$ & 98.2 & 1.8 \\
\hline Total carotenoids (mg) & 0.300 & $0.053^{\mathrm{b}}$ & $0.002^{\mathrm{a}}$ & $0.757^{\mathrm{c}}$ & $<0.001$ & 98.1 & 1.9 \\
\hline Phycoerythrin: chlorophyll $a$ & 4.05 & $4.05^{\mathrm{b}}$ & $6.99^{\mathrm{c}}$ & $0.06^{\mathrm{a}}$ & $<0.001$ & - & - \\
\hline \multicolumn{8}{|l|}{ Phenolics } \\
\hline $\begin{array}{l}\text { Total (mg gallic acid } \\
\text { equivalents) }\end{array}$ & 2.79 & $0.50^{\mathrm{b}}$ & $0.16^{\mathrm{a}}$ & $1.31^{\mathrm{c}}$ & $<0.001$ & 89.5 & 10.5 \\
\hline \multicolumn{8}{|l|}{ Antioxidant activity } \\
\hline DPPH radical scavenging: $\mathrm{EC}_{50}$ & $9.4 \mathrm{mg} \mathrm{mL}^{-1}$ & $52.6 \mathrm{mg} \mathrm{mL}^{-1}$ & $213.1 \mu \mathrm{L} \mathrm{mL}{ }^{-1}$ & AQL & $<0.001$ & 92.0 & 8.0 \\
\hline
\end{tabular}

Measured concentrations for milled residue on a dry weight are presented for information but were not included in ANOVA. Only means for direct carbohydrate and protein measurements on juice are presented. These may be most like the water extraction methods but are included and compared with the different extractions of solid residues. Means in rows followed by the same superscript letter are not significantly different at the $5 \%$ level according to Fisher's protected least significant difference. Relative recovery in the two fractions as \%total material recovered from the screw-press is also shown. $n$. $d$. not determined, $A Q L$ above quantifiable level, *replicate values within category due to the liquid nature of the product, allowing comparison with other fractions. $n=3$ throughout

the juice-pellet fraction, meaning that the $\mathrm{EC}_{50}$ is listed as above quantifiable limit (AQL) in Table 1. The partitioning of total biomass antioxidant activity by screw-pressing was calculated based on the total volume of $\mathrm{EC}_{50}$-strength solution that could be prepared. The proportion of antioxidant activity in the juice fraction was lower than for phenolic content.

Silage quality and silage effluent production The initial $\mathrm{pH}$ of the screw-pressed, chopped and wilted-chopped (SP, Ch and WCh) algal biomass, immediately after their treatment with Safesil silage additive or water as control, ranged from $\mathrm{pH} 6.4$ to 7.0 (Table 2). At day 0, there were no significant two-way interactions on pre-processing methods and additive application; however, there were separate pre-processing and additive effects. Screw-pressing significantly decreased $\mathrm{pH}$, whilst the control silages also had a significantly decreased $\mathrm{pH}$ (Table 2). After 90 days of incubation in vacuum pack bag silos in both a visual inspection and from the perspective of $\mathrm{pH}$ decline, all macroalgae preparations appeared to ensile well. One point of note was the large volume of effluent present in all bags (Fig.
1). The $\mathrm{pH}$ values recorded for the silage solids and corresponding liquid effluent fractions (Table 2) were all below the $\mathrm{pH} 4.4$ level which is considered the highest $\mathrm{pH}$ for satisfactory ensiling of land-based herbage within 7 days (Black 1955). Statistical analysis on the $\mathrm{pH}$ values revealed significant differences between treatments, with $\mathrm{pH}$ values demonstrating similar patterns of $\mathrm{pH}$ change in both the solid silage and the generated effluent.

The relative proportions of $P$. palmata following the screwpressing, wilting and chopping pre-treatments can be seen in Fig. 2. Screw-pressing lost $84 \mathrm{~g} \mathrm{~kg}_{\mathrm{FW}}{ }^{-1}$ of the material in the press, but produced $294 \mathrm{~g} \mathrm{~kg}^{-1}$ of the $\mathrm{FW}$ as a juice. Following ensiling, a further $104 \mathrm{~g} \mathrm{~kg}^{-1}$ or $136 \mathrm{~g} \mathrm{~kg}^{-1}$ (for SP-C and SP-A respectively) of the initial fresh weight was lost as effluent, making the ensiled solid fraction $518 \mathrm{~g} \mathrm{~kg}^{-1}$ or $486 \mathrm{~g} \mathrm{~kg}^{-1}$ (for SP-C and SP-A respectively) of the initial FW with the rest of the weight distributed into the effluent, juice or lost in the initial screw-press process. Material that was chopped did not lose any weight through this process and wilting overnight lost a mere $32 \mathrm{~g} \mathrm{~kg}_{\mathrm{FW}}{ }^{-1}$. Effluents from 
Table 2 Silage $\mathrm{pH}$ and dry matter distribution within the solid and effluent fractions of differently prepared $P$. palmata silages

\begin{tabular}{|c|c|c|c|c|c|c|c|c|c|c|c|c|}
\hline \multirow[b]{2}{*}{ Analyses } & \multicolumn{6}{|c|}{ Treatments } & \multicolumn{3}{|c|}{ Standard error } & \multicolumn{3}{|l|}{$P$ values } \\
\hline & SP-C & SP-A & $\mathrm{Ch}-\mathrm{C}$ & Ch-A & WCh-C & WCh-A & $\begin{array}{l}\text { Pre- } \\
\text { process }\end{array}$ & Additive & $\begin{array}{l}\text { Pre-process } \\
\times \text { additive }\end{array}$ & $\begin{array}{l}\text { Pre- } \\
\text { process }\end{array}$ & Additive & $\begin{array}{l}\text { Pre-process } \\
\times \text { additive }\end{array}$ \\
\hline \multicolumn{13}{|l|}{$\mathrm{pH}$} \\
\hline Pre-ensiling & $6.37^{\mathrm{Aa}}$ & $6.73^{\mathrm{Ab}}$ & $6.73^{\mathrm{Ab}}$ & $7.00^{\mathrm{Bb}}$ & $6.63^{\mathrm{Ba}}$ & $7.03^{\mathrm{Bb}}$ & 0.03 & 0.03 & 0.05 & $<0.001$ & $<0.001$ & 0.340 \\
\hline Solid (ensiled) & $3.58^{\mathrm{a}}$ & $3.57^{\mathrm{a}}$ & $3.98^{\mathrm{c}}$ & $3.61^{\mathrm{a}}$ & $3.76^{\mathrm{b}}$ & $3.69^{\mathrm{b}}$ & 0.02 & 0.01 & 0.02 & $<0.001$ & $<0.001$ & $<0.001$ \\
\hline Effluent (ensiled) & $3.75^{\mathrm{a}}$ & $3.74^{\mathrm{a}}$ & $4.20^{\mathrm{c}}$ & $3.75^{\mathrm{a}}$ & $3.99^{\mathrm{b}}$ & $3.89^{\mathrm{b}}$ & 0.02 & 0.02 & 0.03 & $<0.001$ & $<0.001$ & $<0.001$ \\
\hline \multicolumn{13}{|l|}{ Effluent produced } \\
\hline $\begin{array}{l}\text { Effluent produced } \\
\quad\left(\mathrm{mL} \mathrm{kg}_{\mathrm{FW}}^{-1}\right)\end{array}$ & $267^{\mathrm{a}}$ & $323^{\mathrm{b}}$ & $490^{\mathrm{d}}$ & $447^{\mathrm{c}}$ & $453^{\mathrm{cd}}$ & $463^{\mathrm{cd}}$ & 9.53 & 7.78 & 13.47 & $<0.001$ & 0.493 & 0.010 \\
\hline \multicolumn{13}{|l|}{$\mathrm{DM}\left(\mathrm{g} \mathrm{kg}_{\mathrm{FW}}{ }^{-1}\right)$} \\
\hline Solid & $209.8^{\mathrm{b}}$ & $203.5^{\mathrm{a}}$ & $220.1^{\mathrm{b}}$ & $203.7^{\mathrm{a}}$ & $230.5^{\mathrm{b}}$ & $206.0^{\mathrm{a}}$ & 5.04 & 4.12 & 7.13 & 0.300 & 0.019 & 0.463 \\
\hline Effluent & 130.4 & 130.2 & 101.9 & 142.7 & 122.1 & 129.8 & 9.20 & 7.51 & 13.02 & 0.828 & 0.157 & 0.286 \\
\hline $\begin{array}{l}\text { Effluent proportion of } \\
\text { silage by DM }(\%)\end{array}$ & $16.7^{\mathrm{A}}$ & $21.8^{\mathrm{A}}$ & $29.6^{\mathrm{B}}$ & $34.3^{\mathrm{B}}$ & $28.0^{\mathrm{B}}$ & $29.4^{\mathrm{B}}$ & 1.99 & 1.62 & 2.81 & 0.002 & 0.136 & 0.785 \\
\hline
\end{tabular}

$S P$ screw-pressed, $C h$ chopped only, $W C h$ wilted then chopped, $A$ Safesil additive, $C$ water control. $n=3$. Means in rows followed by the same letter are not significantly different at the $5 \%$ level according to Fisher's protected least significant difference. Where no two-way interaction is present, significances relating to pre-processing technique are represented by capital superscripts, and significances relating to additive effect are represented by lower case superscripts

these pre-processing steps were thus unsurprisingly larger than those from the screw-press with $296 \mathrm{~g} \mathrm{~kg}^{-1}$ (Ch-C), $343 \mathrm{~g} \mathrm{~kg}^{-1}$ (Ch-A), $271 \mathrm{~g} \mathrm{~kg}^{-1}$ (WCh-C) and $285 \mathrm{~g} \mathrm{~kg}^{-1}$ (WCh-A) FWs becoming effluent. The volume of effluent produced from each $P$. palmata sample was considerable compared with that expected from ensiled terrestrial crops using the same ensiling technology (Table 2). Significantly $(P=0.010)$ less effluent was produced from SP-C followed

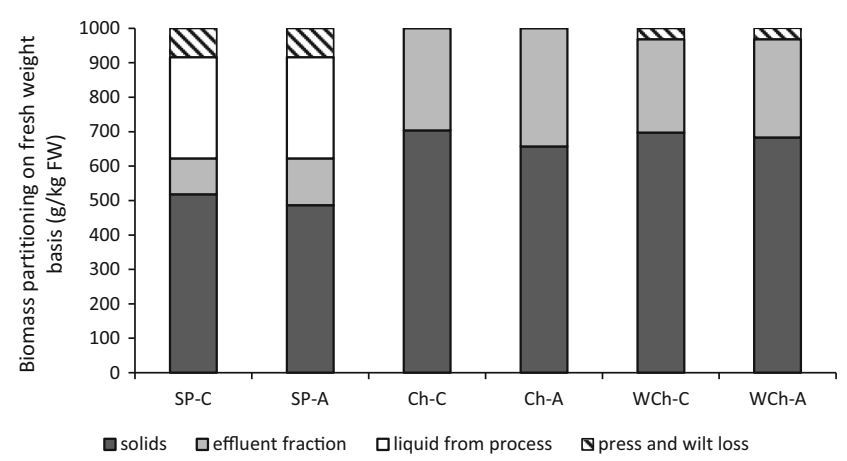

Fig. 2 Fresh weight biomass partitioning from $P$. palmata after different pre-processing methods and ensiling. Biomass partitions of the fresh weight (FW) of P. palmata. Losses of fresh weight was due to screwpressing and wilting losses. White, juice from screw-pressing; light grey, silage effluent; dark grey, solid fraction of the silage; cross-hatched, losses through screw-press and wilting; SP, screw-pressing pre-processing; $\mathrm{Ch}$, chopped only; WCh, wilted, then chopped; $-\mathrm{C}$, water only added in silage preparation; $-\mathrm{A}$, Safesil silage additive added in silage preparation by SP-A, as expected by the process, with larger quantities of effluent produced from treatments $\mathrm{Ch}-\mathrm{A}$, WCh-C, WCh-A and $\mathrm{Ch}-\mathrm{C}$ respectively (Table 2).

Although the solid proportions in each of the ensiled treatments differed, ranging from 657 (Ch-A) to 704 (ChC) $\mathrm{g} \mathrm{kg}_{\mathrm{FW}}{ }^{-1}$ (Fig. 2), when expressed on a DM basis following the ensiling process, there was no significant difference between the total of the solid and effluent DM values in each treatment bag. Treatment DM contents ranged from 161.0 to $176.3 \mathrm{~g} \mathrm{~kg}_{\mathrm{FW}}{ }^{-1}$, though there was a significant $(P=0.019)$ effect of the Safesil additive on the DM content of the ensiled solid fraction, with a higher DM content noted for control treatments than for those treated with Safesil (Table 2). Within the total DM contents, approximately one-third of the total DM fractionated into the silage effluent within the 90 day ensiling period. There was a significant $(P=0.002)$ effect of preprocessing technique on DM conversion to effluent, with screw-pressing producing significantly less DM conversion to effluent, compared with both $\mathrm{Ch}$ and WCh treatments. There was no significant effect of additive or twoway interactions.

The silages contained large proportions of organic acids (Table 3). Within the solid fraction, the main acids were lactic acid (no significant difference between treatments) and acetic acid which was significantly higher $(P<0.001)$ for Ch-C. There were low detectable concentrations of succinic and formic acids in the effluent fractions, not seen in the solids; 
Table 3 Organic acid presence in silage fractions of $P$. palmata

\begin{tabular}{|c|c|c|c|c|c|c|c|c|c|c|c|c|}
\hline \multirow[t]{2}{*}{ Analyses } & \multicolumn{6}{|c|}{ Treatments } & \multicolumn{3}{|c|}{ Standard error } & \multicolumn{3}{|l|}{$\mathrm{P}$ values } \\
\hline & SP-C & SP-A & $\mathrm{Ch}-\mathrm{C}$ & Ch-A & WCh-C & $\begin{array}{l}\text { WCh- } \\
\text { A }\end{array}$ & $\begin{array}{l}\text { Pre- } \\
\text { process }\end{array}$ & Additive & $\begin{array}{l}\text { Pre-process } \times \\
\text { additive }\end{array}$ & $\begin{array}{l}\text { Pre- } \\
\text { process }\end{array}$ & Additive & $\begin{array}{l}\text { Pre-process } \times \\
\text { additive }\end{array}$ \\
\hline \multicolumn{13}{|c|}{ Lactic acid $\left(\mathrm{g} \mathrm{kg}_{\mathrm{DM}}{ }^{-1}\right)$} \\
\hline Solid & 30.1 & 37.9 & 23.7 & 26.2 & 25.6 & 32.2 & 2.60 & 2.12 & 3.68 & 0.086 & 0.085 & 0.760 \\
\hline Effluent & $169.3^{\mathrm{Bb}}$ & $145.8^{\mathrm{Ba}}$ & $142.4^{\mathrm{Ab}}$ & $112.8^{\mathrm{Aa}}$ & $143.6^{\mathrm{Ab}}$ & $130.7^{\mathrm{Aa}}$ & 5.49 & 4.48 & 7.76 & 0.007 & 0.005 & 0.569 \\
\hline Total & $199.3^{\mathrm{B}}$ & $183.7^{\mathrm{B}}$ & $166.1^{\mathrm{A}}$ & $139.0^{\mathrm{A}}$ & $169.2^{\mathrm{A}}$ & $162.9^{\mathrm{A}}$ & 7.07 & 5.77 & 9.99 & 0.007 & 0.068 & 0.595 \\
\hline \multicolumn{13}{|c|}{ Acetic acid $\left(\mathrm{g} \mathrm{kg}_{\mathrm{DM}}{ }^{-1}\right)$} \\
\hline Solid & $9.2^{\mathrm{a}}$ & $10.3^{\mathrm{a}}$ & $22.7^{\mathrm{c}}$ & $5.9^{\mathrm{a}}$ & $16.1^{\mathrm{b}}$ & $10.8^{\mathrm{ab}}$ & 1.22 & 1.00 & 1.73 & 0.051 & $<0.001$ & $<0.001$ \\
\hline Effluent & $49.6^{\mathrm{ab}}$ & $39.7^{\mathrm{a}}$ & $125.1^{\mathrm{c}}$ & $38.6^{\mathrm{a}}$ & $67.0^{\mathrm{b}}$ & $44.2^{\mathrm{ab}}$ & 5.28 & 4.31 & 7.46 & $<0.001$ & $<0.001$ & $<0.001$ \\
\hline \multicolumn{13}{|c|}{ Isobutyric acid $\left(\mathrm{g} \mathrm{kg}_{\mathrm{DM}}{ }^{-1}\right)$} \\
\hline Solid & 13.5 & 15.0 & 16.9 & 10.7 & 15.5 & 19.2 & 1.36 & 1.11 & 1.93 & 0.186 & 0.837 & 0.059 \\
\hline Effluent & $67.4^{\mathrm{bc}}$ & $56.7^{\mathrm{ab}}$ & $87.6^{\mathrm{d}}$ & $48.4^{\mathrm{a}}$ & $73.4^{\mathrm{c}}$ & $67.6^{\mathrm{bc}}$ & 3.07 & 2.51 & 4.34 & 0.179 & $<0.001$ & 0.005 \\
\hline \multicolumn{13}{|c|}{ Isovaleric acid $\left(\mathrm{g} \mathrm{kg}_{\mathrm{DM}}{ }^{-1}\right)$} \\
\hline Solid & $3.6^{\mathrm{A}}$ & $2.0^{\mathrm{A}}$ & $5.7^{\mathrm{AB}}$ & $3.3^{\mathrm{AB}}$ & $5.7^{\mathrm{B}}$ & $8.3^{\mathrm{B}}$ & 1.01 & 0.82 & 1.43 & 0.034 & 0.694 & 0.221 \\
\hline Effluent & 27.6 & 21.2 & 34.7 & 21.7 & 29.4 & 27.1 & 3.06 & 2.50 & 4.33 & 0.604 & 0.062 & 0.478 \\
\hline \multicolumn{13}{|c|}{ Succinic acid $\left(\mathrm{g} \mathrm{kg}_{\mathrm{DM}}{ }^{-1}\right)$} \\
\hline Effluent & $2.3^{\mathrm{b}}$ & $0.7^{\mathrm{ab}}$ & $0.0^{\mathrm{a}}$ & $1.5^{\mathrm{ab}}$ & $4.2^{\mathrm{c}}$ & $2.0^{\mathrm{b}}$ & 0.41 & 0.33 & 0.57 & 0.004 & 0.116 & 0.017 \\
\hline \multicolumn{13}{|c|}{ Formic acid $\left(\mathrm{g} \mathrm{kg}_{\mathrm{DM}}{ }^{-1}\right)$} \\
\hline Effluent & $2.83^{\mathrm{b}}$ & $1.5^{\mathrm{a}}$ & $4.2^{\mathrm{b}}$ & $0.9^{\mathrm{a}}$ & $3.0^{\mathrm{b}}$ & $1.3^{\mathrm{a}}$ & 0.42 & 0.34 & 0.59 & 0.737 & $<0.001$ & 0.233 \\
\hline
\end{tabular}

$S P$ screw-pressed, $C h$ chopped only, $W C h$ wilted then chopped, $A$ Safesil additive, $C$ water control. $n=3$. Means in rows followed by the same letter are not significantly different at the $5 \%$ level according to Fisher's protected least significant difference. Where no two-way interaction is present, significances relating to pre-processing technique are represented by capital superscripts, and significances relating to additive effect are represented by lower case superscripts

for isobutyric and isovaleric acid low concentrations were seen in the solids with higher concentrations in the effluent.

Analyses of the DM content of the effluent fraction showed that there was no significant difference between any of the treatments. However, the same significant $(P<0.001)$ pattern of $\mathrm{pH}$ change (Table 2) noted in the solid fraction was reflected in the effluent fraction. A wider range of acids were found in the effluent fraction and the concentrations were considerably greater than in the solid fraction. Lactic acid was the predominate acid, producing significantly $(P<0.050)$ higher concentrations for SP, followed by $\mathrm{Ch}$ and WCh, and also for those prepared as controls compared with those with Safesil (A). However, there was no two-way interaction for lactic acid. Acetic acid was the second highest concentration across treatments, followed by isobutyric and isovaleric acids. Treatment $\mathrm{Ch}-\mathrm{C}$ had significantly $(P<0.050)$ higher concentrations of all three acids, followed by WCh-C, WCh-A and SP-C, and then SP-A and Ch-C. Solid and effluent samples were also screened for propionic, butyric and valeric acids, but these were not detected in either sample type (data not shown).

\section{Discussion}

Red algae belonging to the phylum Rhodophyta have perhaps been under-exploited in a biorefinery context in the past, as their productivity is lower than for some of the larger brown algae (Werner and Dring 2011). However, they do contain an abundance of useful chemicals, including bioactive molecules and present opportunities for the manufacture of different products in biorefinery cascades. Due to its abundance, availability and ease of cultivation, we have chosen to study $P$. palmata as a potential candidate for a biorefinery process. In addition to studying juice and solid fractions of freshly harvested $P$. palmata, we have investigated the novel possibility of preserving algal biomass by ensilaging protocols similar to those employed for terrestrial forage crops.

Metabolite partitioning within screw-press fractions The removal of useful metabolites from biomass within a biorefining scenario, prior to bulk processing of residues for lower-value products such as sustainable fuel production, can have 
considerable economic advantages (Francavilla et al. 2015). In this study, bulk screw-pressing of fresh $P$. palmata biomass was successfully tested at pilot scale, although the juice appeared to be more dilute than when pressed at bench top scale (Gallagher et al. 2018). Whilst it may be possible to increase the volume and/or the concentration of the juice produced during screw-pressing by adjusting the back pressure, surface water present on the feedstock would also have played a part as the material tested at bench top scale was dried more thoroughly before screw-pressing. Recovery of pressed product was higher in the current study at $84 \%$ rather than $68 \%$ at bench top scale (Gallagher et al. 2018) but partitioning of the utilized products into juice lower at $26 \%$ juice and $74 \%$ residue rather than $37 \%$ and $63 \%$, respectively. The major proportions of the original biomass metabolites measured in this study remained in the screw-pressed residue. This is desirable in a biorefining process as the removal of a significant proportion of the juice close to the harvest site would result in the production of a more concentrated, more transportable material for further processing than the original whole material.

The juice-pellet was high in alkali-soluble protein, chlorophyll and carotenoids. These could have originated from plastid membranes, but only constituted a very small proportion of the recovered biomass. In general, non-water-soluble metabolites partitioned poorly into juice, suggesting that the juice was almost entirely expressed cell sap. The juice contained good concentrations of water-soluble metabolites, being relatively high in WSC, amino acids and phenolic compounds that may have potential value. These areas are discussed in more detail below.

Carbohydrates Many marine macroalgae are high in carbohydrate, both as structural and soluble intracellular compounds. These are predominantly polysaccharides, and many are useful as stabilizers, thickeners and emulsifiers, although the nature of the polymers present does vary widely between different types and species of seaweed (Holdt and Kraan 2011; Mutripah et al. 2014). This study concentrated on 5-min extractions with water as the most likely to provide useful comparisons between the WSC content of SP juice and the residue fractions. In general, many of the larger insoluble structural polysaccharides of macroalgae require lengthy extraction procedures with aggressive media or appropriate enzyme preparations to break down algal structures prior to solubilization. In the current study, all the readily soluble carbohydrate was extractable from the solid residue with water, as extraction with sodium carbonate or sodium hydroxide (Jiao et al. 2012) for $5 \mathrm{~min}$ did not significantly increase the measured values (data not shown).

The main storage carbohydrate in P. palmata is floridoside (Martinez and Rico 2008). This 1-linked galactose (Lahaye and Vigouroux 1992) has been reported to be present in high concentrations in this species (Martinez and Rico 2008). Endogenously floridoside is thought to be the main sugar involved in osmoregulation (Simon-Colin et al. 2002). Therapeutically, it is reported to be a modifier of the immune system with potential anti-tumour activity (Courtois et al. 2008).

Several larger polymers are reported to be abundant in P. palmata (Mutripah et al. 2014). Carrageenans are components of algal cell walls made up of galactose and 3,6anhydrogalactopyranose, but despite being high-molecularweight polysaccharides, most have been shown to be extractable with short treatments in hot water. They may be a component of the additional carbohydrate proportion removed by hot water over a cold water extraction in this study. They could also be present in the juice if elevated temperatures are experienced in the screw-press. They have widespread applications in the food industry due to their useful gelling properties (Holdt and Kraan 2011). The other main polysaccharide within P. palmata, constituting up to $35 \%$ dry weight, is xylan. Composed of $\beta-(1-3)$ and $\beta-(1-4)$ linked D-xylose units containing no sulphate, ester or methoxyl groups, these structural polysaccharides are known to have some water solubility (Percival and Chanda 1950). Studies have previously shown galactose to be the only or the major sugar component present in carbohydrates extracted from P. palmata with water after non-osmotically stressful treatments (Lahaye and Vigouroux 1992), so floridoside (1-linked galactose) may reasonably be assumed to be the major source of the carbohydrate component of the juice produced by screw-pressing.

Protein and amino acids $P$. palmata has frequently been noted for its high protein content (Galland-Irmouli et al. 1999; Maehre et al. 2014), perhaps commonly as high as $20 \%$ and sometimes up to $35 \%$, which is comparable with more traditional sources of protein like chicken and other meats (Dumay et al. 2013; Mouritsen et al. 2013). However, values of this order have generally only been reported when crude protein has been estimated from measurements of total nitrogen (crude protein $=6.25 \times \mathrm{N}$ ). Bjarnadottir et al. $(2018)$ consider that this method is likely to considerably over-estimate the actual protein content in P. palmata. Certainly, studies which measure protein content directly report lower values (Schiener et al. 2017). This study would support that the protein content of the solid material was just under $5 \%$, comparable with the $11 \%$ protein in Schiener et al. (2017) when taking effects of seasonal variation into account. $P$. palmata protein content in the summer was around half that found in the winter (GallandIrmouli et al. 1999) which is a result of much higher carbohydrate concentrations during the growing season (Adams et al. 2011a; b; Schiener et al. 2015). The protein of P. palmata is considered to be a good source of several essential amino acids relative to the recommended daily intake, particularly 
for lysine (Maehre et al. 2014; Misurcova et al. 2014). Both glutamate and aspartate, which can be used in the food industry to confer seasoning properties, are also major components (Mouritsen et al. 2013). When screw-pressing, the proteins of $P$. palmata biomass did not partition well into the juice fraction, although water-soluble protein was unsurprisingly better than less soluble proteins. However, free amino acids partitioned particularly well with nearly $30 \%$ of the total tissue content found in the juice, and preliminary evidence indicated that several essential amino acids (lysine, histidine, phenylalanine and leucine) were present.

Phenolics The phenolic content of red algae is generally lower than that of brown algae (Holdt and Kraan 2011), and the concentration of phenolic compounds measured in this study was of the same order as that reported by Schiener et al. (2017). Phenolic compounds often have antioxidant properties, and P. palmata has been reported to have a range of classes of hydrophilic antioxidant components (Wang et al. 2010). Consequently, measurements of phenolic content can show correlations with antioxidant activity, but the relationship is variable, and other compounds can be involved (Farvin and Jacobsen 2013; Machu et al. 2015). In this study, the phenolic compounds present in the juice-pellet did not result in any detectable antioxidant activity. The juice had one-third the concentration of phenolics as the solid residue, but the half maximal effective concentration $\left(\mathrm{EC}_{50}\right)$ was four times higher. Therefore, the relative antioxidant activity of the compounds in the juice was lower than of those remaining in the residue. Nevertheless, compounds with useful antioxidant and radiation protection activities may be present in the juice, and natural antioxidants have a considerable value as food additives to improve shelf life (Farvin and Jacobsen 2013).

Ensiling process The manufacturers claim that the additive (Safesil) lowers crop $\mathrm{pH}$, inhibits potential spoilage microorganisms, reduces silage effluent production and enhances the aerobic stability of terrestrial crop silages (Kelvincave 2020). The addition of Safesil to Ch P. palmata did significantly improve the ensiling process for this pre-processing treatment, relative to the addition of water as a control, producing a lower $\mathrm{pH}$ (solid and effluent fractions), lower acetic (solid fraction) and volatile fatty acids (effluent fraction) concentrations. However, when SP and WCh P. palmata were treated with Safesil, similar improvements were not detected compared with the water controls. Therefore, we conclude that an addition of Safesil does not benefit the ensiling of $P$. palmata and the pre-processing techniques of screw-pressing or wilting appear sufficient at improving the ensiling process.

All pre-processing methods, with and without the addition of Safesil, produced an ensiled product for longer-term storage of this readily degradable biomass. Overall, there was no difference in total DM content of each silage (solid and liquid fraction combined); however, the solid fraction demonstrated a significantly higher DM for the control compared with Safesil treatments. For all treatments, a large percentage of the DM moved from the biomass into the effluent fraction after 90 days of ensiling. The effluent produced from the screw-pressed silage unsurprisingly produced a lower quantity of effluent compared with the $\mathrm{Ch}$ and WCh treatments. The screw-pressing pre-treatment also significantly reduced the $\mathrm{pH}$ of the biomass prior to ensiling on day 0 . However, by day 90 of ensiling, the $\mathrm{pH}$ had reduced to satisfactory silage levels for all, though the screw-pressed samples remained the lowest for the residue and lower or equal to ChA for the effluent. The high effluent production from $P$. palmata could be both beneficial and problematic for future biofuel use. Through effluent production, DM and other components were lost from the solid fraction into the effluent that may affect the energy potential of the solid biomass fraction. For example, if the solid ensiled P. palmata was to be used for anaerobic digestion, the methane potential of the ensiled biomass would be lower as some of the utilizable methanogenic substrates (particularly acetic acid) of the biomass would transfer to the effluent. Herrmann et al. (2015) demonstrated that methane yield of the seaweed biomass could only be preserved if the effluent was anaerobically digested along with the ensiled seaweed. Alternatively, the effluent could be seen as a relatively high DM flowable feedstock, suitable for continuous fermentation encompassing membrane filtration systems. Further work is required to identify and quantify the compounds present in both P. palmata silage and the effluent and to ascertain their potential as metabolite sources.

\section{Conclusions}

Red algae have perhaps been under-utilized in the past, as their productivity is lower than for some of the larger brown algae (Werner and Dring 2011). However, they do present opportunities for the production of different products in biorefinery cascades. P. palmata is plentiful enough that it can be collected and screw-pressed at pilot scale. The major part of the original biomass metabolite suite remained in the solid residue, indicating that the juice fraction is of limited use for future processing and contains little DM. If metabolite utilization is not feasible or desirable, $P$. palmata can also be successfully ensiled without additives and used as a potential bioenergy feedstock. Once ensiled, though, a large proportion of the DM is lost in the relatively high volume of effluent (compared to terrestrial biomass) which may limit opportunities for its use in this fashion in the future. Further work is required to investigate chemical partitioning in the ensiled liquid and solid fractions and to establish if there are any additional compounds present in the effluent that may have biorefinery/therapeutic benefits. 
Acknowledgements We are grateful to Sam Gill, Luned Roberts and the late John Corton of IBERS, Aberystwyth University; Fleuriane Fernandez and Maria Scolamacchia of CSAR, University of Swansea, UK; and Emma Judd, Harper Adams University, UK, for their help collecting the seaweed used in this study. We also thank the late John Corton for managing the screw-pressing operations.

Funding This work was supported by the Engineering and Physical Sciences Research Council EP/K014900/1 and the following projects for providing time spent writing this manuscript: BBS/E/W/0012843B (BBSRC Core Strategic Programme in resilient crops: Oats) and WEFO/ ERDF grant number 80851 (BEACON+).

Open Access This article is licensed under a Creative Commons Attribution 4.0 International License, which permits use, sharing, adaptation, distribution and reproduction in any medium or format, as long as you give appropriate credit to the original author(s) and the source, provide a link to the Creative Commons licence, and indicate if changes were made. The images or other third party material in this article are included in the article's Creative Commons licence, unless indicated otherwise in a credit line to the material. If material is not included in the article's Creative Commons licence and your intended use is not permitted by statutory regulation or exceeds the permitted use, you will need to obtain permission directly from the copyright holder. To view a copy of this licence, visit http://creativecommons.org/licenses/by/4.0/.

\section{References}

Adams JMM, Ross AB, Anastasakis K, Hodgson EM, Gallagher JA, Jones JM, Donnison IS (2011a) Seasonal variation in the chemical composition of the bioenergy feedstock Laminaria digitata for thermochemical conversion. Bioresour Technol 102:226-234

Adams JMM, Toop TA, Donnison IS, Gallagher JA (2011b) Seasonal variation in Laminaria digitata and its impact on biochemical conversion routes to biofuels. Bioresour Technol 102:9976-9984

Adams JMM, Bleathman G, Thomas D, Gallagher JA (2017) The effect of mechanical pre-processing and different drying methodologies on bioethanol production using the brown macroalga Laminaria digitata (Hudson) JV Lamouroux. J Appl Phycol 29:2463-2469

Banskota AH, Stefanova R, Sperker S, Lall SP, Craigie JS, Hafting JT, Critchley AT (2014) Polar lipids from the marine macroalga Palmaria palmata inhibit lipopolysaccharide-induced nitric oxide production in RAW264.7 macrophage cells. Phytochemistry 101: 101-108

Bjarnadottir M, Adalbjornsson BV, Nilsson A, Slizyte R, Roleda MY, Hreggvidsson GO, Fridjonsson OH, Jonsdottir R (2018) Palmaria palmata as an alternative protein source: enzymatic protein extraction, amino acid composition, and nitrogen-to-protein conversion factor. J Appl Phycol 30:2061-2070

Black W (1955) The preservation of seaweed by ensiling and bactericides. J Sci Food Agric 6:14-23

Courtois A, Simon-Colin C, Boisset C, Berthou C, Deslandes E, Guezennec J, Bordron A (2008) Floridoside extracted from the red alga Mastocarpus stellatus is a potent activator of the classical complement pathway. Mar Drugs 6:407-417

Dumay J, Clement N, Morancais M, Fleurence J (2013) Optimization of hydrolysis conditions of Palmaria palmata to enhance Rphycoerythrin extraction. Bioresour Technol 131:21-27

Farrar K, Bryant DN, Turner L, Gallagher JA, Thomas A, Farrell M, Humphreys MO, Donnison IS (2012) Breeding for bio-ethanol production in Lolium perenne L.: association of allelic variation with high water-soluble carbohydrate content. Bioenergy Res 5:149-157
Farvin KHS, Jacobsen C (2013) Phenolic compounds and antioxidant activities of selected species of seaweeds from Danish coast. Food Chem 138:1670-1681

Ferguson A, Sims A (1974) The regulation of glutamine metabolism in Candida utilis: the role of glutamine in the control of glutamine synthetase. J Gen Microbiol 80:159-171

Folch J, Lees M, Stanley GHS (1957) A simple method for the isolation and purification of total lipides from animal tissues. J Biol Chem 226:497-509

Francavilla M, Manara P, Kamaterou P, Monteleone M, Zabaniotou A (2015) Cascade approach of red macroalgae Gracilaria gracilis sustainable valorization by extraction of phycobiliproteins and pyrolysis of residue. Bioresour Technol 184:305-313

Gallagher JA, Turner LB, Adams JMM, Dyer PW, Theodorou MK (2017) Dewatering treatments to increase dry matter content of the brown seaweed, kelp (Laminaria digitata ((Hudson) JV Lamouroux)). Bioresour Technol 224:662-669

Gallagher JA, Turner LB, Adams JMM, Barrento S, Dyer PW, Theodorou MK (2018) Species variation in the effects of dewatering treatment on macroalgae. J Appl Phycol 30:2305-2316

Galland-Irmouli AV, Fleurence J, Lamghari R, Lucon M, Rouxel C, Barbaroux O, Bronowicki JP, Villaume C, Gueant JL (1999) Nutritional value of proteins from edible seaweed Palmaria palmata (Dulse). J Nutr Biochem 10:353-359

Harnedy PA, FitzGerald RJ (2013) In vitro assessment of the cardioprotective, anti-diabetic and antioxidant potential of Palmaria palmata protein hydrolysates. J Appl Phycol 25:17931803

Harnedy PA, Soler-Vila A, Edwards MD, FitzGerald RJ (2014) The effect of time and origin of harvest on the in vitro biological activity of Palmaria palmata protein hydrolysates. Food Res Int 62:746752

Herrmann C, FitzGerald J, O'Shea R, Xia A, O'Kiely P, Murphy JD (2015) Ensiling of seaweed for a seaweed biofuel industry. Bioresour Technol 196:301-313

Holdt SL, Kraan S (2011) Bioactive compounds in seaweed: functional food applications and legislation. J Appl Phycol 23:543-597

Jiao GL, Yu GL, Wang W, Zhao XL, Zhang JZ, Ewart SH (2012) Properties of polysaccharides in several seaweeds from Atlantic Canada and their potential anti-influenza viral activities. Jf Ocean Univ China 11:205-212

Johnson HE, Merry RJ, Davies DR, Kell DB, Theodorou MK, Griffith GW (2005) Vacuum packing: a model system for laboratory-scale silage fermentations. J Appl Microbiol 98:106-113

Kamm B, Schonicke P, Hille C (2016) Green biorefinery - industrial implementation. Food Chem 197:1341-1345

Kelvincave (2020) Better preservation for more profitable silage. https:// kelvincave.com/forage/silage-preservatives/safesil-silage-additivepreservation/. Accessed 16 Apr 2020

Lahaye M, Vigouroux J (1992) Liquefaction of dulse (Palmaria palmata (L) Kuntze) by a commercial enzyme preparation and a purified endo-3-1,4-D-xylanase. J Appl Phycol 4:329-337

Lichtenthaler H, Wellburn A (1983) Determinations of total carotenoids and chlorophylls $\mathrm{a}$ and $\mathrm{b}$ of leaf extracts in different solvents. Biochem Soc Trans 11:591-592

Loureiro R, Gachon CMM, Rebours C (2015) Seaweed cultivation: potential and challenges of crop domestication at an unprecedented pace. New Phytol 206:489-492

Lowry OH, Rosebrough NJ, Farr AL, Randall RJ (1951) Protein measurement with the Folin phenol reagent. J Biol Chem 193:265-275

Machu L, Misurcova L, Ambrozova JV, Orsavova J, Mlcek J, Sochor J, Jurikova T (2015) Phenolic content and antioxidant capacity in algal food products. Molecules 20:1118-1133

Maehre HK, Malde MK, Eilertsen KE, Elvevoll EO (2014) Characterization of protein, lipid and mineral contents in common 
Norwegian seaweeds and evaluation of their potential as food and feed. J Sci Food Agric 94:3281-3290

Martel CM, Parker JE, Jackson CJ, Warrilow AGS, Rolley N, Greig C, Morris SM, Donnison IS, Kelly DE, Kelly SL (2011) Expression of bacterial levanase in yeast enables simultaneous saccharification and fermentation of grass juice to bioethanol. Bioresour Technol 102: $1503-1508$

Martinez B, Rico JM (2008) Changes in nutrient content of Palmaria palmata in response to variable light and upwelling in Northern Spain. J Phycol 44:50-59

Misurcova L, Bunka F, Ambrozova JV, Machu L, Samek D, Kracmar S (2014) Amino acid composition of algal products and its contribution to RDI. Food Chem 151:120-125

Morgan KC, Wright JLC, Simpson FJ (1980) Review of chemicalconstituents of the red alga Palmaria palmata (Dulse). Econ Bot 34:27-50

Mouritsen OG, Dawczynski C, Duelund L, Jahreis G, Vetter W, Schroder M (2013) On the human consumption of the red seaweed dulse (Palmaria palmata (L.) Weber \& Mohr). J Appl Phycol 25:17771791

Mutripah S, Meinita MDN, Kang JY, Jeong GT, Susanto AB, Prabowo R, Hong YK (2014) Bioethanol production from the hydrolysate of Palmaria palmata using sulfuric acid and fermentation with brewer's yeast. J Appl Phycol 26:687-693

Percival EGV, Chanda SK (1950) The xylan of Rhodymenia palmata. Nature 166:787-788

Sampath-Wiley P, Neefus CD (2007) An improved method for estimating R-phycoerythrin and R-phycocyanin contents from crude aqueous extracts of Porphyra (Bangiales, Rhodophyta). J Appl Phycol 19:123-129

Schiener P, Black KD, Stanley MS, Green DH (2015) The seasonal variation in the chemical composition of the kelp species Laminaria digitata, Laminaria hyperborea, Saccharina latissima and Alaria esculenta. J Appl Phycol 27:363-373

Schiener P, Zhao SF, Theodoridou K, Carey M, Mooney-McAuley K, Greenwell C (2017) The nutritional aspects of biorefined Saccharina latissima, Ascophyllum nodosum and Palmaria palmata. Biomass Convers Biorefin 7:221-235

Schmid M, Guiheneuf F, Stengel DB (2014) Fatty acid contents and profiles of 16 macroalgae collected from the Irish Coast at two seasons. J Appl Phycol 26:451-463
Sekar S, Chandramohan M (2008) Phycobiliproteins as a commodity: trends in applied research, patents and commercialization. J Appl Phycol 20:113-136

Shi QM, Wang AJ, Lu ZH, Qin CJ, Hu J, Yin J (2017) Overview on the antiviral activities and mechanisms of marine polysaccharides from seaweeds. Carbohydr Res 453-454:1-9

Simon-Colin C, Bessieres MA, Deslandes E (2002) An alternative HPLC method for the quantification of floridoside in salt-stressed cultures of the red alga Grateloupia doryphora. J Appl Phycol 14:123-127

Soomro RR, Ndikubwimana T, Zeng XH, Lu YH, Lin L, Danquah MK (2016) Development of a two-stage microalgae dewatering process a life cycle assessment approach. Front Plant Sci 7

Suutari M, Leskinen E, Fagerstedt K, Kuparinen J, Kuuppo P, Blomster J (2015) Macroalgae in biofuel production. Phycol Res 63:1-18

Takara D, Khanal SK (2011) Green processing of tropical banagrass into biofuel and biobased products: an innovative biorefinery approach. Bioresour Technol 102:1587-1592

van Ginneken VJT, Helsper J, de Visser W, van Keulen H, Brandenburg WA (2011) Polyunsaturated fatty acids in various macroalgal species from north Atlantic and tropical seas. Lipids Health Dis 10:104

Wang T, Jonsdottir R, Kristinsson HG, Hreggvidsson GO, Jonsson JO, Thorkelsson G, Olafsdottir G (2010) Enzyme-enhanced extraction of antioxidant ingredients from red algae Palmaria palmata. LWTFood Sci Technol 43:1387-1393

Werner A, Dring M (2011) Aquaculture explained no. 27 - cultivating Palmaria palmata. Bord Iascaigh Mhara, p 76

Yemm EW, Cocking EC (1955) The determination of amino-acids with ninhydrin. Analyst 80:209-213

Yemm EW, Willis AJ (1954) The estimation of carbohydrates in plant extracts by anthrone. Biochem J 57:508-514

Yuan Y, Macquarrie DJ (2015) Microwave assisted step-by-step process for the production of fucoidan, alginate sodium, sugars and biochar from Ascophyllum nodosum through a biorefinery concept. Bioresour Technol 198:819-827

Zhao WH, Duan MR, Zhang X, Tan TW (2018) A mild extraction and separation procedure of polysaccharide, lipid, chlorophyll and protein from Chlorella spp. Renew Energy 118:701-708

Publisher's note Springer Nature remains neutral with regard to jurisdictional claims in published maps and institutional affiliations. 